\title{
Lifetime Musical Activities and Cognitive Function of the Elderly
}

\section{Aktivitas Bermusik Sepanjang Hidup dan Fungsi Kognitif pada Lanjut Usia}

\author{
Alicia Nevriana* Pandu Riono* Tri Budi W. Rahardjo** Adji Kusumadjati***
}

\begin{abstract}
*Departemen Biostatistik dan Ilmu Kependudukan Fakultas Kesehatan Masyarakat Universitas Indonesia, **Center for Ageing Studies Universitas Indonesia, ***Kementerian Kesehatan Republik Indonesia
\end{abstract}

\begin{abstract}
Decreasing cognitive function of the elderly is one of the most common problems that might affect their quality of life. Music is an element that is believed to be able to contribute to the quality of life of the elderly. However, whether musical activities that are done throughout the life span related to cognitive function is unclear. In this research, we evaluated the association between lifetime musical activities and cognitive function. Fifty three older adults from three nursing homes in East Jakarta were selected and interviewed regarding their characteristics and lifetime musical activities. Cognitive function was also measured using Mini Mental State Examinaion (MMSE). The results of this preliminary study revealed that a possibility of an association between lifetime musical activities and cognitive function of the elderly was indicated. The result also showed that the participants who were not actively involved in musical activities during their lifetime were twice more likely to develop cognitive function impairment than the elderly who were actively involved in musical activities, after being adjusted by the characteristics. These correlational results suggest the beneficial effect of musical activities throughout the life span on cognitive functioning for the elderly.

Keywords: Aging, elderly, cognitive function, music
\end{abstract}

\footnotetext{
Abstrak

Penurunan fungsi kognitif merupakan salah satu masalah umum pada lanjut usia yang mampu memengaruhi kualitas hidup mereka. Musik merupakan sebuah elemen yang dipercaya mampu berkontribusi terhadap kualitas hidup mereka. Meski demikian, hubungan antara aktivitas musikal yang dilakukan sepanjang hidup dan fungsi kognitif lansia belum diketahui secara pasti. Pada penelitian ini, hubungan antara aktivitas musikal sepanjang hidup dan fungsi kognitif dievaluasi. Lima puluh tiga lansia penghuni panti tresna werdha di Jakarta Timur dipilih dan diwawancarai terkait karakteristik dan aktivitas musikal sepanjang hidup mereka. Fungsi kognitif juga diukur menggunakan MMSE. Hasil penelitian ini menunjukkan
}

adanya kemungkinan asosiasi antara aktivitas musikal sepanjang hidup dan fungsi kognitif lansia. Hasil penelitian juga menunjukkan bahwa partisipan yang tidak aktif melakukan aktivitas musikal sepanjang hidupnya dua kali lebih berpeluang untuk mengalami gangguan fungsi kognitif dibandingkan dengan mereka yang aktif melakukan aktivitas musikal, setelah disesuaikan dengan karakteristiknya. Hasil korelasi ini mengisyaratkan pengaruh bermanfaat dari aktivitas musikal sepanjang hidup terhadap fungsi kognitif lansia.

Kata kunci: Penuaan, lanjut usia, fungsi kognitif, musik

\section{Introduction}

As the world moved toward the $21^{\text {st }}$ century, a demographical change started happening around the world. For the first time in human history, the elderly population would exceed the population of children under five. ${ }^{1}$ It is estimated that in 2030, the number of the elderly population will reach 1 billion around the world. ${ }^{2}$ In Indonesia, the number of elderly population in 2010 was 18 million people and is estimated to reach 28 million in $2030 .^{3}$ The increasing number of elderly population will inevitably bring certain challenges in various fields. In health, the challenge is how to maintain the quality of life and health status of the elderly whose population grows rapidly. The maintenance of elder people's quality of life and health status is important in order to allow them enjoying their later life. In other words, the elderly should be able to experience the 'optimal aging'. ${ }^{4}$ To be able to achieve the optimal aging, one should continue his/her

Alamat Korespondensi: Alicia Nevriana, Departemen Biostatistika dan Ilmu Kependudukan FKM Universitas Indonesia, Gd. A Lt. 2 Kampus Baru UI Depok 16424, Hp.08996806729, e-mail: anevriana@yahoo.com 
life functions at the highest possible level by remaining active physically, cognitively, and socially as long as possible. ${ }^{5}$

Unfortunately, the elderly is a population that is vulnerable to the decline in those functional abilities. Several studies showed that the cognitive decline proportions were greater in elderly than in other age groups, made it the most at risk population for such a cognitive impairment. ${ }^{6}$ In Indonesia, the proportions of elderly who suffered from cognitive impairment ranged from $62-89.6 \% .^{7,8}$ Due to the negative effects of cognitive impairment to elder people's life, a way to counter such impairment should be seek immediately. ${ }^{9}$

Music has long been believed to have such a potential to contribute to elder people's quality of life. ${ }^{10}$ One of the important influences of music is its ability to affect elder people's cognitive functioning either for short or long term, although it couldn't be generalized for all cognitive processes. ${ }^{11,12}$ Many studies about the influence of music to elder people's cognitive functioning had been done, though most of them explored the music as a form of intervention. The study about daily musical activities in elder people's life and its connections to their cognitive functioning has rarely been done, whereas many musical activities such as playing musical instruments, singing in the choir, and watching the concerts had been indicated to have positive association with elder people's cognitive functioning. 13-24 Thus, the researchers are interested to evaluate the possible association between lifetime musical activities and cognitive function of the elderly.

\section{Methods}

The study adopted the cross-sectional design and was conducted from April - May 2012 in three nursing homes in East Jakarta (2 public or government run, 1 private). Fifty-three older adults were interviewed regarding their characteristics (including age, sex, education, marital status, former occupation, health) and lifetime musical activities using a questionnaire which was developed from the questionnaires used by Patchen, ${ }^{15}$ Cohen et al, ${ }^{16}$ and Laukka. ${ }^{17}$ The information about the cognitive function was obtained through Mini Mental State Examination (MMSE) which has been translated to Bahasa as used by Purnakarya and Sudja. ${ }^{8,18}$ Data analysis that was performed was descriptive analysis and mutivariable association.

\section{Results}

Mean age of participants was 75.85 years old $(\mathrm{SD}=$ 8.75; range between 60 and 92). Most of the participants were divorced/widowed $(94.3 \%)$, women $(66.0 \%)$, with low educational background $(43.4 \%)$ never attended school or didn't finish elementary school). Only $13.2 \%$ of the participants had no previous occupation; the other participants had previously worked as a merchant $(17.0 \%)$, civil servant $(17.0 \%)$, private sector employee $(9.4 \%)$, farmer, fisherman, laborer $(3.8 \%)$, or other occupations $(39.6 \%)$. Although $43.4 \%$ claimed to have no serious diseases, $18.9 \%$ of the participants claimed to have hypertension, 9.4\% claimed to suffer from heart disease, and $28.3 \%$ others claimed to suffer from diabetes mellitus, stroke, brain injury, and combination from the diseases mentioned before.

Lifetime musical activities were defined as musical activities that were undertaken in the past (before entering the nursing homes) and at the moment (after entering the nursing homes). The activities that were used as the predictors were playing musical instrument and singing. A musically active elder was defined as an elder who kept on playing musical instrument or singing continuously before and after lived at the nursing homes. According to the results, only $43.4 \%$ of the participants were musically active. In this research, the participants' cognitive function was measured using MMSE with maximum score of 30. Mean MMSE score of participants was 20.1 ( $\mathrm{SD}=6.8)$, but there was a difference in mean MMSE score between participants who lived at public nursing homes and private nursing home. Mean MMSE score for elders who lived at private nursing home $(25.8, \mathrm{SD}=3.8)$ was higher than those who lived at public nursing homes $(16.7, \mathrm{SD}=$ 5.8). Cognitive impairment was categorized using MMSE score with cutoff point 24. If the participant's MMSE score was lower than 24, he/she was indicated to have cognitive impairment. The results showed that most of the participants $(62.3 \%)$ had already had cognitive impairment at the time of the study.

The association between lifetime musical activities and cognitive function of participants was described in Table 1 . The table showed that musically inactive participants shared the largest proportion of cognitive impairment $(70 \%)$. The odds ratio of 2.1 (95\% CI : $0.7-6.6)$ meant that the odds of developing cognitive impairment for elders who were musically inactive was 2.1 times higher than musically active elders. Multivariable analysis was conducted using the risk-factor model with cognitive function as the dependent variable and musical activities as the main independent variable. Although several variables were theoretically indicated as confounding variables, in this research, there were only two variables that were included in this study: age and sex. This was due to limitation of the sample which resulted in the invariability of the data from other variables such as education and disease history. Therefore, those variables were not adjusted in the analysis.

It could also be seen from the multivariable analysis that the changing in odds ratio (OR) after being adjust- 
Table 1. The Association between Lifetime Musical Activities and Cognitive Function of Participants

\begin{tabular}{|c|c|c|c|c|c|c|c|}
\hline \multirow{3}{*}{$\begin{array}{l}\text { Musical } \\
\text { Activities }\end{array}$} & \multicolumn{4}{|c|}{ Elder's Cognitive Function } & \multirow{3}{*}{ OR } & \multirow{3}{*}{ 95\% CI } & \multirow{3}{*}{ P value } \\
\hline & \multicolumn{2}{|c|}{ Normal } & \multicolumn{2}{|c|}{ Impaired } & & & \\
\hline & $\mathbf{n}$ & $\%$ & $\mathbf{n}$ & $\%$ & & & \\
\hline Active & 11 & 47.8 & 12 & 52.2 & 2.1 & $0.7-6.6$ & 0.185 \\
\hline Inactive & 9 & 30.0 & 21 & 70.0 & & & \\
\hline
\end{tabular}

Table 2. Odds Ratio Changing in Musical Activities Before and After Being Controlled by Confounding Variables

\begin{tabular}{lcccc}
\hline Variable & Crude OR & 95\% CI & Adjusted OR & 95\% CI \\
\hline Musical activities & 2.1 & $0.7-6.6$ & 2.0 & $0.6-7.1$ \\
\hline
\end{tabular}

ed by age and sex was relatively small (Table 2). The musical activities OR after being controlled by confounding variables was $2.0(95 \% \mathrm{CI}=0.6-7.1)$, meant that the odds of cognitive impairment in musically inactive elders was two times more than musically active elders after being adjusted by sex and age.

\section{Discussion}

One of the limitations of this research was the small sample size which was caused by several factors, such as the illness of the previously chosen respondents or their refusal to be interviewed. In addition, this research was conducted at the nursing homes, so the results could only be applied to the elders who lived at the institutions and could not be generalized for the whole population. Another limitation was the design for the research (which was cross sectional) that made it impossible to analyze the causal relationships. The cross sectional design also enhanced the chance of the biases because all variables were measured at the same time. In this research, the method we used to collect the data was only the interview. It might limit the accuracy of some the data, since we did not cross check the interview result with another source of the data. For example, we did not cross check the disease history data with the medical records of the respondents.

This research was aimed to explore the association between lifetime musical activities with the cognitive function of the elderly at the nursing homes in East Jakarta. The results showed that overall mean MMSE score was $20.1(\mathrm{SD}=6.8)$, lower than the cutoff point 24 which was used by Spar \& La Rue and Albert \& Freedman to screen the cognitive impairment.6,19 However, there was disparity of mean MMSE score between the elders who lived at public and private nursing homes. The mean MMSE score for elders who lived at private nursing homes $(25.8, \mathrm{SD}=3.8)$ was higher than those who lived at public nursing homes (16.7, SD $=5.8$ ). These results indicated the differences in the elders' characteristics between those two places and it might be linked to the education, since Crum, et al in Albert \& Freedman stated that the MMSE score was highly influenced by education. ${ }^{19}$

The overall proportion of the elders who suffered from cognitive impairment was $62.3 \%$, close to the result by Lestari, but smaller than the result by Sudja. ${ }^{7,8}$ The usage of 24 points cutoff quite influenced the cognitive impairment proportion in this research. Considering the characteristics of the elders (which most of them had low education status), the usage of the more appropriate cutoff point should be encouraged, as Hogervorst et al stated. ${ }^{20}$ Besides, the usage of modified MMSE for the elders with low education should also be considered, since several parts of MMSE test like the writing part was quite hard to be done by the low-educated elders and might enhance the possibility of bias to the results.

Although the term musical activities could refer to several music-related activities, this research focused on playing musical instruments and singing only. Playing musical instruments was chosen because the elders who had ever played or were still playing the musical instruments tended to have higher musical activities than those who didn't play musical instruments, while singing was one of the most common musical activities that the elders did in their life. ${ }^{15}$ It was shown that the number of elders who were continuously playing musical instruments or singing was smaller than those who were not. This could be influenced by several factors, such as the level of musical activities done in the childhood, the duration of one's involvement in certain musical activities, and the availability of the musical activities. ${ }^{7}$ It was confirmed from the researchers' observation that not every nursing home provided specific musical activities, e.g. playing musical instruments. This absence of the program might be due to lack of human resources. However, even when specific program was provided, it was observed that not every elder could access it, for example because of the physical limitations. Another result from this research showed that the number of elder who had cognitive impairment was bigger in musically inactive group, indicating the positive association between lifetime musical activities and cognitive function of the elders. Although it wasn't statistically significant $(\mathrm{p}$ value $=$ 0.185 ), it did not mean that there was no association between them.

After being adjusted by the confounding variables (age and sex), the odds for musically inactive elders to develop cognitive impairment was twice bigger than the musically active elders. Several other potentially confounding variables such as education and disease history 
weren't included in the analysis due to the limitation of the sample which was too homogenous, causing the relatively small differences between the crude and adjusted OR. Besides, the differences in respondent's level of participation made it unable to conduct further analysis based on the type of nursing homes (public or private). Overall, the results obtained in this study appeared to be consistent with previous researches on musical activities and cognitive function. ${ }^{14-21}$ Despite the limitation of this study to inference the results to general population, there were several possible explanations for the mechanisms behind the associations between lifetime musical activities and cognitive function.

Basically, performing music was an activity that could train complex motor and cognitive functions, which couldn't be done by other cognitive activities. ${ }^{22}$ When someone performed music, his/her nervous system was demanded to do certain tasks which wouldn't have been needed in other activities, e.g. controlling the rhythm and specific pitch. This might act as a base for certain differences in several aspects of a musically active person'snervous system. ${ }^{23}$ Besides, according to Strait \& Kraus, ${ }^{24}$ because musical training and experiences must involve several sensory aspects including motor function, reading musical notes, and hearing function, it was suspected that it could influence several parts of the brain and cognitive area. In other words, since the functions of human body's structure will function better if being used or trained simultaneously, the one who actively stimulate it by playing musical instruments or singing or other musical activities is believed to have better body's structure function (e.g. the brain) than the one who doesn't. In the end, this will cause the cognitive function differences between the ones who actively do lifetime musical activities and the ones who do not. 25

Several studies using neuroimaging technique showed the presence of structural changes in human's brain that might be connected to certain cognitive abilities. Those structural changes caused the differences between muscians and non-musicians in cortex's volume which was linked to hearing and grey matters' concentration in motor cortex (Gaser \& Schlaug in Zatorre et al) and in cerebellum's hemisphere though it could only be applied to man (Hutchinson et al in Zatorre et al). ${ }^{23}$

Cognitive function differences between musically active elders and not might also be linked to nervous system plasticity - the ability of the nervous system to form new neural network through a reshaping mechanism. ${ }^{24}$ In general, a musically active person would start doing the musical activities at the early stage of his/her life, when brain plasticity was at its peak. ${ }^{22}$ Furthermore, according to Monaghan et al in Hanna-Pladdy \& MacKay and Zatorre \& McGill musical activities like playing musical instruments, creating music, and listening to music were able to stimulate several cognitive functions and were useful information for training induced brain plasticity which might happen at later age as a compensation for cognitive decrease related to age. ${ }^{14,23}$ Similar statement was also expressed by Stern in Geda et al which stated that participation in cognitive activities, including playing musical instruments was most likely to encourage and stimulate the formation of neural networks in the brain that could inhibit the onset of dementia and Alzheimer's disease. ${ }^{21}$

\section{Conclusions}

In conclusion, the elderly might benefit from the musical activities they continuously do, since the findings from this study showed that the elderly who were not actively involved in musical activities during their lifetime were twice more likely to develop cognitive impairment than the elderly who were actively involved in musical activities, after being adjusted by the characteristics. However, in order to get optimum benefit from the musical activities, one needs to be introduced to music and musical activities as early as possible. It is also suggested to reform the education curriculum so that music education could be enjoyed by the children as early as possible and continuously. In order to achieve this, there needs to be a change in people's mindset so music and art will be considered as an important branch of knowledge. The development of musical activities in nursing homes should also be considered, since musical activities should be done continuously. It means that the support in the form of facilities and human resources should be provided, with various kinds of activities, regarding the elders' interests and abilities. Periodic evaluation should also be conducted so the activities could always be improved. Further research with large-scale sample is needed in order to capture the phenomenon in the whole elderly population. A national cohort study could also be considered to further investigate the association between lifetime musical activities and cognitive function.

\section{Acknowledgements}

The authors thank the elderly who had graciously participated in this study, Social Agency of Jakarta Provincial Government, and the social workers from all the nursing homes.

\section{References}

1. United Nations. Department of Economic and Social Affairs, Population Division. World population prospects: the 2010 revision [online]. 2011 [cited 2011 Nov 25]. http://esa.un.org/unpd/wpp/unpp/p2k0data.asp.

2. Dobriansky PJ, Suzman RM, Hodes RJ. Why population aging matters: a global perspective. Washington, DC: U.S. Department of State and Department of Health and Human Services, National Institute of Aging, \& National Institute of Health; 2007. 
3. BAPPENAS, BPS, UNFPA. Proyeksi penduduk indonesia (Indonesia population projection) 2005 - 2025. Jakarta: Badan Perencanaan Pembangunan Pembangunan Nasional, Badan Pusat Statistik, \& United Nations Population Fund; 2005.

4. Syamsuddin. Mencapai optimum aging pada lansia [online]. 2008 Aug 26 [diakses tanggal 18 Maret 2012]. Diunduh dari: http://www.depsos.go.id/modules.php?name=News\&file $=$ article $\&$ sid $=797$

5. Hays T. Well-being in later life through music. Australasian Journal on Ageing. 2005; 24(1): 28-32.

6. Spar JE, La Rue A. Clinical manual of geriatric psychiatry. Washington, DC: American Psychiatric Publishing Inc; 2006.

7. Lestari P. Hubungan antara aktivitas sosial dan karakteristik lansia dengan gangguan fungsi kognitif pada lansia di Wilayah Kerja Puskesmas Mekar Wangi Kota Bogor tahun 2008 [Thesis]. Depok: Universitas Indonesia; 2008.

8. Sudja MFA. Hubungan antara konsumsi tempe dan tahu dengan fungsi kognitif lanjut usia. [Disertasi]. Depok: Universitas Indonesia; 2009.

9. Surprenant AM, Neath I. Cognitive aging. In: Wilmoth JM, Ferraro KF, editors. Gerontology: perspectives and issues. 3rd ed. New York: Springer Publishing Company, LLC; 2007. p. 89-109.

10. Sixsmith A, Gibson G. Music and the wellbeing of people with dementia. Ageing \& Society. 2007; 27(1): 127-45.

11. Mammarella N, Fairfield B, Cornoldi C. Does music enhance cognitive performance in healthy older adults? The Vivaldi effect. Aging Clin Exp [serial on the internet] Res. 2007;19 (5):1-6 [cited 2011 jun 18]. Available from: http://www.brandimontelab.it/pubpdf/nmam/aging_07_57\%20Mammarella.pdf.

12. Irish M, Cunningham CJ, Walsh JB, Coakley D, Lawlor BA, Robertson $\mathrm{IH}$, et al. Investigating the enhancing effect of music on autobiographical memory in mild Alzheimer's Disease. Dementia and Geriatric Cognitive Disorders. 2006; 22(1): 108-20.

13. Ashley JG. The relation between different forms of activity and cognition in older adults [Dissertation]. United States: Graduate School Southern Illinois University Carbondale; 2008.

14. Hanna-Pladdy B, MacKay A. The relation between instrumental musical activity and cognitive aging. Neuropsychology. 2011; 25(3): 378-86.

15. Patchen JH. The relationships among current musical activity level and selected musical and demographic variables within an elderly population [Dissertation]. United States: Graduate Faculty of the School of Music Indiana University; 1986.

16. Cohen A, Bailey B, Nilsson T. The importance of music to seniors. Psychomusicology. 2002; 18(1-2): 89-102. Available from: http://www.upei.ca/ musicog/research/docs/newjan05/Cohen-BaileyNilsson.pdf

17. Laukka P. Uses of music and psychological well-being among the elderly. Journal Happiness Study. 2007; 8(2): 215-41.

18. Purnakarya I. Analisis pola makan dan faktor lainnya yang berhubungan dengan kejadian demensia pada lansia di Wilayah Jakarta Barat Tahun 2007. [Thesis]. Depok: Universitas Indonesia; 2008.

19. Albert SM, Freedman VA. Public health and aging: maximizing function and well-being. New York: Springer Publ Co; 2010.

20. Hogervorst E, Mursjid F, Ismail RI, Prasetyo S, Nasrun M, Mochtar, et al. Validation of two short dementia screening tests in Indonesia. In: Jacobsen SR, editor. Vascular dementia: risk factors, diagnosis and treatment. New York: Nova Sci Publ, Inc; 2011.

21. Geda YE, Topazian HM, Lewis RA, Roberts RO, Knopman DS, Pankratz VS, et al. Engaging in cognitive activities, aging, and mild cognitive impairment: A Population-Based Study. J Neuropsychiatry Clin Neurosci [serial on the internet]. 2011; 23(2): 149-54 [cited 2012 Jan 10]. Available from: http://neuro.psychiatryonline.org/data/Journals /NP/4318/jnp00211000149.pdf

22. Patston LLM, Tippett LJ. The effect of background music on cognitive performance in musicians and nonmusicians. Music Perception. 2011; 29 (2): 173-83.

23. Zatorre RJ, Chen JL, Penhune VB. When the brain plays music: Auditory-motor interactions in music perception and production. Nat Rev Neurosci [serial on the internet]. 2007; 8(7): 547-558 [cited 2010 Aug 8]. Available from: http://www.nature.com/nrn/journal/v8/n7/ $\mathrm{pdf} / \mathrm{nrn} 2152 . \mathrm{pdf}$.

24. Strait D, Kraus N. Playing music for a smarter ear: cognitive, perceptual and neurobiological Evidence. Music Perception. 2011; 29(2): 133-46.

25. Schneck DJ, Berger DS. The music effect: music physiology and clinical applications. Philadelphia: Jessica Kingsley Publ; 2006. 